\author{
Jacek Charatynowicz ${ }^{\text {a)* }}$ \\ a) The Alcide De Gasperi University of Euroregional Economy / Wyższa Szkoła Gospodarki Euroregionalnej im. Alcide De Gasperi \\ "Corresponding author / Autor korespondencyjny: j.charatynowicz@gmail.com
}

\title{
Cryptoassets as Contemporary Threats to the Economic Security of the Country
}

\section{Kryptoaktywa jako współczesne zagrożenia bezpieczeństwa ekonomicznego państwa}

\begin{abstract}
Aim: The aim of this article is to present the conclusions of a research conducted in the area of identifying threats to the economic interests of the state related to the trading of cryptoassets, as well as the presentation of legal solutions functioning in the cryptoasset environment and possible remedial actions to be taken by the state authorities competent in this regard.

Introduction: Due to the technological features, undefined legal status, regulatory and organizational risks of this instrument, the threats related to the trading of cryptoassets are one of the most important current threats from the point of view of the economic security of the country. They are identified both by domestic and foreign financial market supervision authorities, tax and law enforcement authorities, and those dealing with counteracting money laundering and the financing of the terrorists. The article presents the identified risk areas, legal regulations in the field of trading in these assets, and regulatory perspectives. An attempt was also made to describe the actions necessary to be taken to mitigate the threats.

Methodology: In this work, theoretical research was used, such as: analysis of literature, on legal and strategic studies as well as industry literature, synthesis, generalization and inference. In addition, analysis was carried out of the legal acts related to the regulation of the market of cryptoassets, international strategic documents describing this market and the Polish financial supervision. Draft legal acts of a legislative nature were also presented. Conclusions: The market of cryptoassets is subject to constant legal, organizational and institutional transformations. Its socio-economic environment is also changing. Due to the characteristics of cryptoassets, their dispersed and unregulated nature, institutions of this market, both entities participating in transaction brokerage, as well as natural persons, can be used for money laundering, concealing property from various forms of crime. However, the identified vulnerabilities do not pose a significant threat to the economic security of the country - they are of a sectoral nature. The relevant state institutions undertake specific activities in order to counteract threats, both of a legal, institutional and organizational nature.

Keywords: cryptoassets, threats to economic security, legal regulations in the area of cryptoassets, counteracting money laundering and financing of terrorism, mitigation of threats related to cryptoassets

Type of article: review article
\end{abstract}

Received: 29.10.2021; Reviewed: 20.11.2021; Accepted: 07.12.2021;

Author's ORCID ID: J. Charatynowicz - 0000-0003-0484-4078;

Please cite as: SFT Vol. 58 Issue 2, 2021, pp. 164-178, https://doi.org/10.12845/sft.58.2.2021.10;

This is an open access article under the CC BY-SA 4.0 license (https://creativecommons.org/licenses/by-sa/4.0/).

\begin{abstract}
ABSTRAKT
Cel: Celem niniejszego artykułu jest przedstawienie wniosków z badań przeprowadzonych w zakresie identyfikacji zagrożeń dla ekonomicznych interesów państwa związanych z obrotem kryptoaktywami, a także prezentacja rozwiązań prawnych funkcjonujących w otoczeniu kryptoaktywów oraz możliwych do podjęcia działań zaradczych przez właściwe w tym zakresie organy państwa.

Wprowadzenie: Z uwagi na cechy technologiczne, niedookreślony status prawny, ryzyka regulacyjne i organizacyjne tego instrumentu, zagrożenia związane z obrotem kryptoaktywami są jednymi z najistotniejszych aktualnych zagrożeń z punktu widzenia bezpieczeństwa ekonomicznego państwa. Są one identyfikowane zarówno przez krajowe, jak i zagraniczne organy nadzoru nad rynkiem finansowym, organy podatkowe, ścigania oraz zajmujące się przeciwdziałaniem praniu pieniędzy i finansowaniu terroryzmu. W artykule przedstawiono zidentyfikowane obszary zagrożeń, regulacje prawne obowiązujące w zakresie obrotu tymi aktywami, perspektywy regulacyjne. Podjęto także próbę opisania koniecznych do podjęcia działań w celu mitygacji zagrożeń. Metodologia: W przedmiotowej pracy wykorzystano badania teoretyczne, takie jak: analiza literatury, opracowań prawnych i strategicznych oraz piśmiennictwo branżowe, syntezę, uogólnienie oraz wnioskowanie. Ponadto dokonano analizy aktów prawnych związanych z regulacją rynku kryptoaktywów, międzynarodowych dokumentów strategicznych opisujących rynek kryptoaktywów oraz polskiego nadzoru finansowego. Przedstawiono również projektowane akty prawne o charakterze legislacyjnym.
\end{abstract}


Wnioski: Rynek kryptoaktywów podlega nieustannym przeobrażeniom prawnym, organizacyjnym i instytucjonalnym. Zmienia się również jego otoczenie społeczno-ekonomiczne. Z uwagi na cechy kryptoaktywów, ich rozproszony i nieuregulowany charakter, instytucje tego rynku, zarówno podmioty biorące udział w pośrednictwie transakcyjnym, jak również osoby fizyczne, mogą być wykorzystywane do prania pieniędzy, ukrywania mienia pochodzącego z różnych form przestępczości. Zidentyfikowane podatności nie stanowią jednak istotnego zagrożenia dla bezpieczeństwa ekonomicznego państwa - mają charakter sektorowy. Właściwe instytucje państwa podejmują określone aktywności w celu przeciwdziałaniu zagrożeniom, zarówno o charakterze prawnym, instytucjonalnym, jak i organizacyjnym.

Słowa kluczowe: kryptoaktywa, zagrożenia bezpieczeństwa ekonomicznego, regulacje prawne obszaru kryptoaktywów, przeciwdziałanie praniu pieniędzy oraz finansowaniu terroryzmu, mitygacja zagrożeń związanych z kryptoaktywami

Typ artykułu: artykuł przeglądowy

Przyjęty: 29.10.2021; Zrecenzowany: 20.11.2021; Zaakceptowany: 07.12.2021;

Identyfikator ORCID autora: J. Charatynowicz - 0000-0003-0484-4078;

Proszę cytować: SFT Vol. 58 Issue 2, 2021, pp. 164-178, https://doi.org/10.12845/sft.58.2.2021.10;

Artykuł udostępniany na licencji CC BY-SA 4.0 (https://creativecommons.org/licenses/by-sa/4.0/).

\section{Introduction}

Currently, in the security environment, we can distinguish various types of threats - military and non-military - and prove their importance from the point of view of state security. The most important non-military threats include: internal political crises, asymmetric and hybrid threats, economic and financial vulnerabilities, terrorism, threats in cyberspace, organized crime, corruption, human and drug trafficking as well as money laundering [1].

"An emergency is a situation or condition that threatens someone or in which someone feels threatened; also: someone who creates such a situation" [2], while according to another definition, a threat is a situation in which there is a probability of a dangerous state for the environment. Taking as the basis the domains in which the threat may occur, the already mentioned military and non-military threats can be distinguished. Among the latter, the following threats can be distinguished: political, economic, psychosocial, ecological, internal and others" [3].

In addition to the threats, it is also worth pointing to the key megatrends important from the point of view of security, i.e. trends with a particular strength, scope and area of impact. They include: technological revolution, reconfiguration of balance of power in the international arena, crisis of liberal democracy, demographic prospects and climate change, and the so-called black swans - a term used in economics for an unexpected event that (almost) no one can predict [4].

Among the indicated trends, distinguished can be the technological revolution in various aspects of its impact, digital development, cyberspace, artificial intelligence, big data, which affect many areas of the state's functioning. Therefore, they pose challenges to the political decision-makers, representatives of the world of science and the security analysts in the context of their impact on security, including state security.

The aim of this article is both an analytical and scientific presentation of the risks associated with the trading of cryptoassets, as well as presenting conclusions in the field of institutional and operational methods of counteracting them.

\section{Wstęp}

Aktualnie w środowisku bezpieczeństwa możemy wyróżnić różnego rodzaju zagrożenia - militarne i pozamilitarne - oraz dowodzić ich istotności z punktu widzenia bezpieczeństwa państwa. Do najważniejszych zagrożeń o charakterze pozamilitarnym należy zaliczyć: wewnętrzne kryzysy polityczne, zagrożenia asymetryczne, hybrydowe, podatności gospodarcze i finansowe, terroryzm, zagrożenia w cyberprzestrzeni, zorganizowaną przestępczość, korupcję, handel ludźmi i narkotykami oraz pranie pieniędzy [1].

„Zagrożenie to sytuacja lub stan, które komuś zagrażają lub w której ktoś czuje się zagrożony; też: ktoś, kto stwarza taką sytuację" [2], natomiast zgodnie z inną definicją zagrożenie jest to sytuacja, w której pojawia się prawdopodobieństwo powstania stanu niebezpiecznego dla otoczenia. Przyjmując za podstawę dziedziny, w których może wystąpić zagrożenie, wyróżnia się - wspomniane już - zagrożenia militarne i niemilitarne. Wśród tych drugich można z kolei wyszczególnić zagrożenia: polityczne, ekonomiczne (gospodarcze), psychospołeczne, ekologiczne, wewnętrzne i inne" [3] .

Oprócz zagrożeń, warto również wskazać na kluczowe megatrendy istotne $z$ punktu widzenia bezpieczeństwa, tj. trendy o szczególnej sile, zakresie i obszarze oddziaływania. Zalicza się do nich: rewolucję technologiczną, rekonfigurację układu sił na arenie międzynarodowej, kryzys demokracji liberalnej, perspektywy demograficzne i zmiany klimatyczne oraz tzw. czarne łabędzie - termin stosowany w naukach ekonomicznych oznaczający nieoczekiwane zdarzenie, którego (prawie) nikt nie jest w stanie przewidzieć [4].

Wśród wskazanych trendów wyróżnić należy rewolucję technologiczną w różnych aspektach jej oddziaływania, rozwój cyfrowy, cyberprzestrzeń, sztuczną inteligencję, duże zbiory danych (ang. big data), które mają wpływ na wiele obszarów funkcjonowania państwa. W związku z tym stawiają one przed decydentami politycznymi, przedstawicielami świata nauki oraz analitykami ds. bezpieczeństwa wyzwania w kontekście ich wpływu na bezpieczeństwo, w tym bezpieczeństwo państwa. 
Celem przedmiotowego artykułu jest zarówno analityczne i naukowe przybliżenie zagrożeń związanych z obrotem kryptoaktywami, jak również przedstawienie wniosków w zakresie instytucjonalnego i operacyjnego im przeciwdziałania.

\section{Kryptoaktywa}

Rynek instrumentów opartych o technologię blockchain - łańcuch bloków - podlega nieustannym zmianom konstrukcji technologicznej, otoczenia prawnego i ekonomicznego, wzrostu ilości kryptoaktywów oraz ich kapitalizacji. W efekcie tych zmian, jak również z uwagi na malejące znaczenie tradycyjnych rynków finansowych' [5], czynniki te wpływają na zachowania inwestorów indywidualnych i instytucjonalnych. Coraz istotniejszymi obszarami inwestycyjnymi oraz miejscem alokacji aktywów jest rynek nieruchomości, inwestycje w obligacje, alternatywne formy inwestycji (złoto, bursztyn, dzieła sztuki), rynek Forex, ale również kryptoaktywa ( $w$ tym tokeny inwestycyjne).

Wraz z rozwojem rynku wirtualnych walut, kryptowalut i tokenów zmienia się również postrzeganie przez regulatorów tego obszaru usług płatniczych i inwestycyjnych. Z punktu widzenia raportów Europejskiego Banku Centralnego: Wirtualne systemy walut z 2012 r. [6] oraz Wirtualne systemy walut - dalsza analiza z 2015 r. [7], wirtualne waluty to „rodzaj nieuregulowanych, cyfrowych pieniędzy, które są wydawane i zazwyczaj kontrolowane przez ich wydawców, akceptowane i używane przez członków określonej wirtualnej społeczności". Natomiast w kontekście raportów Europejskiego Urzędu Papierów Wartościowych i Giełd oraz Europejskiego Urzędu Nadzoru Bankowego wyrażone w stanowisku z 9 stycznia 2019 r. kryptoaktywa (ang. cryptoassets) to „rodzaj majątku prywatnego, który zależy przede wszystkim od kryptografii i technologii rozproszonej księgi rozrachunkowej" [8-9].

Zgodnie z raportem Financial Conduct Authority, Guidance on Cryptoassets, Consultation Paper CP19/3 [10] ze stycznia 2019 r., kryptoaktywa najczęściej są wykorzystywane:

- jako środek wymiany, zwykle funkcjonujący jako zdecentralizowane narzędzie umożliwiające kupno i sprzedaż towarów oraz usług lub ułatwiający regulację zasad działania usług płatniczych;

- jako inwestycja, w której firmy i konsumenci są bezpośrednio narażeni na ryzyko związane z posiadaniem i handlem kryptoaktywami lub pośrednio narażeni przez posiadanie lub handel instrumentami finansowymi, które odnoszą się do kryptoaktywów;

- jako wsparcie pozyskiwania kapitału i/lub tworzenia zdecentralizowanych sieci przez publiczną emisję tokenów (ang. initial coin offering) lub inne mechanizmy dystrybucji.

Ze względu na uwarunkowania techniczne oraz skomplikowany charakter infrastruktury systemu dokonanie terminologicznego rozróżnienia kryptoaktywów nie jest zadaniem prostym. Zgodnie z cytowanym już raportem ESMA, Advice Initial

\footnotetext{
According to the information contained in "Puls Biznesu", Investors focus on motor yachts, an attractive form of investment is financial involvement in yachts, which may bring profits of $8-12 \%$ per year.
}

Zgodnie z materiałem informacyjnym zawartym w „Pulsie Biznesu”, Inwestorzy stawiają na jachty motorowe, atrakcyjna forma inwestowania to zaangażowanie finansowe w jachty, które może przynieść zyski w kwotach 8-12\% w skali roku. 
virtual currency: digital currency, cryptocurrency, cryptoasset and digital asset [11].

Polish scientific and practical literature can be divided into the following terms: cryptocurrencies, virtual currencies and digital currencies [12]

Due to the civil and legal nature of trading, the need to stabilize and develop the market, transparency and ensuring the security of transactions, the market of cryptoassets is subject to national regulations that relate to the following aspects:

- cryptocurrency is a property right, is closely related to the economic interest of the rightholder, is transferable [13], is freely tradable and inherited;

- due to the identified threats, the market of cryptocurrency is subject to regulations in the area of counteracting its use for money laundering or financing terrorism;

- the possibility of taxing income from trading in cryptoassets;

- in the context of using cryptocurrencies in the area of payment services, regulations have been developed for this market, analogous to those for selected institutions of the payment services market;

- due to the use of cryptocurrencies as an investment instrument, there are regulations for this market, analogous to those for selected investment institutions and investment fund companies.

The structure and tasks of the national system of counteracting money laundering and financing terrorism are described in the Act of 1 March 2018 on counteracting money laundering and financing terrorism [14]. According to the document mentioned above, the authority competent to counteract these phenomena is the General Inspector of Financial Information. Obligated institutions and cooperating units are also essential elements of the system.

The definition of an obligated institution is subjective in nature - it indicates a catalogue of institutions ( 25 of them are characterized in the current Act), on which obligations in the area of counteracting money laundering and financing terrorism have been imposed [15]. Due to the definition of the catalogue of obligated institutions, the so-called cryptocurrency exchange platforms have been obliged to fulfil obligations in the area of counteracting money laundering and financing terrorism in the following areas:

- applying the so-called financial security measures;

- reporting to the GIFI the information on transactions equivalent to EUR 15,000 (in case of cash transactions equivalent to EUR 10,000), suspicious transactions;

- conducting risk analysis as part of identifying suspicious transactions;

- creating technological possibilities to suspend transactions/blocking the account.

The cooperating units are government administration bodies, local government units and other state organizational units, as well as the National Bank of Poland, the Polish Financial Supervision Authority and the Supreme Audit Office. The definition of the cooperating unit is included in art. 2 clause 2 point 8 of the Act of 1 March 2018 on counteracting money laundering and financing terrorism [14].
Coin Offerings and Crypto-Assets, kryptoaktywa możemy podzielić na waluty cyfrowe, kryptowaluty oraz tokeny, natomiast w dokumentach Departamentu Skarbu Stanów Zjednoczonych zbiorczą nazwą wymienialna waluta wirtualna (ang. convertible virtual currency) określa się: walutę cyfrową (ang. digital currency), kryptowaluty (ang. cryptocurrency), wartości oparte na kryptografii (ang. cryptoasset) oraz aktywa cyfrowe (ang. digital asset) [11].

W polskojęzycznej literaturze naukowej oraz literaturze praktycznej można wyróżnić podział na następujące pojęcia: kryptowaluty, waluty wirtualne oraz waluty cyfrowe [12].

Ze względu na cywilno-prawny charakter obrotu, konieczność stabilizacji oraz rozwoju rynku, transparentności i zapewnienia bezpieczeństwa transakcji rynek kryptoaktywów podlega krajowym regulacjom, które dotyczą następujących aspektów:

- kryptowaluta jest prawem o charakterze majątkowym, pozostaje w ścisłym związku z ekonomicznym interesem uprawnionego, jest zbywalna [13], podlega swobodnemu obrotowi oraz dziedziczeniu;

- z uwagi na identyfikowane zagrożenia rynek kryptowalut podlega regulacjom w zakresie przeciwdziałania wykorzystywaniu go do prania pieniędzy lub finansowania terroryzmu;

- możliwość opodatkowania dochodów osiąganych z tytułu obrotu kryptoaktywami;

- w kontekście wykorzystania kryptowalut w zakresie usług o charakterze płatniczym wypracowano regulacje dla tego rynku, analogiczne jak dla wybranych instytucji rynku usług płatniczych;

- ze względu na wykorzystanie kryptowalut jako instrument inwestycyjny istnieją regulacje dla tego rynku, analogiczne jak dla wybranych instytucji o charakterze inwestycyjnym oraz towarzystw funduszy inwestycyjnych.

Struktura i zadania krajowego systemu przeciwdziałania praniu pieniędzy oraz finansowaniu terroryzmu została opisana w ustawie z dnia 1 marca 2018 r. o przeciwdziałaniu praniu pieniędzy oraz finansowaniu terroryzmu [14]. Zgodnie z przywołanym dokumentem, organem właściwym w zakresie przeciwdziałania tym zjawiskom jest Generalny Inspektor Informacji Finansowej. Istotnymi elementami systemu są również instytucje obowiązane i jednostki współpracujące.

Definicja instytucji obowiązanej ma charakter podmiotowy - wskazuje na katalog instytucji (w obowiązującej ustawie scharakteryzowanych jest ich 25), na które nałożono obowiązki w zakresie przeciwdziałania praniu pieniędzy oraz finansowaniu terroryzmu [15]. W związku z takim określeniem katalogu instytucji obowiązanych tzw. platformy wymiany kryptowalut zostały zobligowane do realizowania obowiązków w obszarze przeciwdziałania praniu pieniędzy oraz finansowaniu terroryzmu w zakresie:

- stosowania wobec klientów tzw. środków bezpieczeństwa finansowego;

- raportowania do GIIF informacji o transakcjach stanowiących równowartość 15000 euro (w przypadku realizacji transakcji gotówkowych o równowartości 10000 euro), transakcji podejrzanych;

- prowadzenia analizy ryzyka w ramach identyfikowania transakcji podejrzanych;

- stworzenia technologicznych możliwości do wstrzymania transakcji/blokady rachunku. 
On the other hand, from the point of view of the transparency of the cryptocurrency market, transaction security, and trading participants, it was important to introduce regulations on cryptoassets (virtual currencies) to the aforementioned Act, in particular their statutory definition, account definition and transactions.

According to the legal definition, virtual currencies are "digital representations of value that are not:

a) legal tender issued by the NBP, foreign central banks or other public administration bodies;

b) an international unit of account established by an international organization and accepted by individual countries belonging to or cooperating with that organization [16];

c) electronic money within the meaning of the Act of 19 August 2011 on payment services;

d) a financial instrument within the meaning of the Act of 29 July 2005 on Trading in Financial Instruments [17];

e) bill of exchange or check;

and is tradable for legal tender and accepted as a medium, and can be electronically stored or transferred or be traded in e-commerce" [14].

In turn, in art. 2 clause 2 point $17 \mathrm{e}$ of this Act stipulates that "a virtual currency (cryptocurrency) account is a collection of identification data kept in an electronic form, which provides authorized persons with the possibility to use virtual currency units, including carrying out their exchange transactions" [14].

Important from the point of view of counteracting money laundering and terrorist financing was the extension of the catalogue of obligated institutions to include entities conducting business activity, consisting in the provision of services in the area [18]:

- exchanges between virtual currencies and means of payment

- exchanges between virtual currencies,

- brokerage in exchange,

- account maintenance.

The amendment to the act [19] introduced additional solutions in the area of cryptoassets, i.e. in case of providing services in the area of trading or exchange between cryptoassets and a fiat currency (Latin fides - faith, legal tender) such activity is treated as a regulated activity (art. 129a.1). Therefore, in case of activities in this area, there will be an obligation to make an entry in the register of virtual currencies kept by the minister responsible for public finances. However, failure to meet the regulatory requirement will result in an administrative fine of up to PLN 100,000. Pursuant to the new regulations, the activities mentioned above may only be performed by natural persons who have not been legally convicted of an intentional crime: against the activities of state institutions and local government, against the administration of justice, credibility of documents, property, economic turnover or property interests and money turnover, and also legal persons or organizational units in which the partners have not been legally convicted on the terms set out above in relation to natural persons or for a fiscal offense.

What is also important, in accordance with the presented amendment in the area of obligated institutions operating in the field of trading or exchange between cryptoassets and fiat
Jednostkami współpracującymi są organy administracji rządowej, organy jednostek samorządu terytorialnego oraz inne państwowe jednostki organizacyjne, a także Narodowy Bank Polski, Komisja Nadzoru Finansowego i Najwyższa Izba Kontroli. Definicja jednostki współpracującej została zawarta w art. 2 ust. 2 pkt 8 ustawy z dnia 1 marca 2018 r. o przeciwdziałaniu praniu pieniędzy oraz finansowaniu terroryzmu [14].

Natomiast z punktu widzenia przejrzystości rynku kryptowalut, bezpieczeństwa transakcji, uczestników obrotu, istotne było wprowadzenie do wymienionej ustawy regulacji dotyczących kryptoaktywów (walut wirtualnych), w szczególności ich definicji ustawowej, definicji rachunku i transakcji.

Zgodnie z definicją prawną wirtualne waluty to "cyfrowe odwzorowanie wartości, które nie jest:

a) prawnym środkiem płatniczym emitowanym przez NBP, zagraniczne banki centralne lub inne organy administracji publicznej;

b) międzynarodową jednostką rozrachunkową ustanawianą przez organizację międzynarodową i akceptowaną przez poszczególne kraje należące do tej organizacji lub z nią współpracujące [16];

c) pieniądzem elektronicznym $w$ rozumieniu ustawy $z$ dnia 19 sierpnia 2011 r. o usługach płatniczych;

d) instrumentem finansowym w rozumieniu ustawy $z$ dnia 29 lipca 2005 r. o obrocie instrumentami finansowymi [17];

e) wekslem lub czekiem;

oraz jest wymienialne w obrocie gospodarczym na prawne środki płatnicze i akceptowane jako środek wymiany, a także może być elektronicznie przechowywane lub przeniesione albo może być przedmiotem handlu elektronicznego" [14].

Z kolei w art. 2 ust. 2 pkt 17e tej ustawy określono, że „rachunek wirtualnej waluty (kryptowaluty) to prowadzony w formie elektronicznej zbiór danych identyfikacyjnych zapewniających osobom uprawnionym możliwość korzystania z jednostek walut wirtualnych, w tym przeprowadzania transakcji ich wymiany" [14].

Istotnym z punktu widzenia przeciwdziałania praniu pieniędzy oraz finansowaniu terroryzmu było rozszerzenie katalogu instytucji obowiązanych o podmioty prowadzące działalność gospodarczą, polegającą na świadczeniu usług w zakresie [18]:

- wymiany pomiędzy walutami wirtualnymi i środkami płatniczymi,

- wymiany pomiędzy walutami wirtualnymi,

- pośrednictwa w wymianie,

- prowadzenia rachunku.

Nowelizacja przedmiotowej ustawy [19] wprowadziła dodatkowe rozwiązania w obszarze kryptoaktywów, tj. w przypadku świadczenia usług w zakresie obrotu lub wymiany między kryptoaktywami a walutą fiducjarną (łac. fides - wiara, legalny środek płatniczy) taka aktywność traktowana jest jako działalność regulowana (art. 129a.1). W związku z tym, w przypadku działalności $w$ tym zakresie, będzie istniał obowiązek dokonania wpisu do rejestru działalności w zakresie walut wirtualnych prowadzonego przez ministra właściwego do spraw finansów publicznych. Natomiast brak spełnienia wymogu regulacyjnego będzie implikował karą administracyjną o wartości do 100000 zł. Zgodnie z nowymi przepisami powyższa działalność może być wykonywana jedynie przez 
currency, the obligation to report transactions to the General Inspector of EUR 1,000, and to apply a full catalogue of financial security measures or the obligation to verify the client was introduced, including establishing personal data, PESEL number or date of birth, number of the identification document or address, determining the data of the real beneficiary - that is the person who actually exercises control over the customer.

The reason for this change was the analysis of the financial intelligence unit of transactions on this market provided by cryptocurrency exchange offices/stock exchanges and the related risks, as well as the need to implement EU regulations.

Another area of cryptoasset regulation is the tax system. Pursuant to the Act of 26 July 1991 on personal income tax [20], revenues from trading in virtual currencies were classified as revenues from capital or capital gains. The above category includes: sale, cryptocurrency payment, payment of other liabilities, sale on the free market, stock exchange or exchange office. At the same time, specific rules for taxing cryptoassets were indicated. These revenues will not be combined with other revenues from cash capitals (capital gains). Qualification as a source of income - cash capital - will be made even when the taxpayer will generate income from trading virtual currencies as part of his business. As a consequence, the loss incurred on trading in virtual currencies will not be deductible from the taxpayer's other income, e.g. from the sale of shares or from the conducted business activity.

In the context of profits from cryptocurrency trading, in connection with the conducted business activity, the provisions of art. $7 \mathrm{~b}$ of the Act of 15 February 1992 on corporate income $\operatorname{tax}[21]$ apply, in which the revenues were defined as: sale, cryptocurrency payment, payment of other liabilities, sale on the free market, stock exchange, exchange office.

Tax on natural and legal persons ranges from $17 \%$ to $32 \%$, according to the tax scale.

A separate issue is the possibility of taxing cryptocurrency transactions with VAT. However, according to the interpretation of the Ministry of Finance, "the activity in the area of buying and selling cryptocurrencies is subject to VAT as a paid service, for VAT purposes, the concept of currencies used as legal tender also includes the so-called cryptocurrency. This means that the sale and exchange of a cryptocurrency for traditional currency and vice versa, as well as the exchange of one cryptocurrency for another, as long as it is subject to VAT, benefits from VAT exemption" [22].

Another aspect of the cryptoasset regulation is the possibility of running a business for stock exchanges/exchange offices in the area of trading cryptocurrency based on the provisions of the Act of 19 August 2011 on payment services [23]. The most convenient form of conducting business in the area of cryptocurrency trading under this Act, due to low regulatory requirements, is the so-called small payment institution.

On 1 December 2016, on the initiative of the Polish Financial Supervision Authority, a Working Group for the development of financial innovations (the so-called FinTech) was established. The aim of the Group was to identify legal, regulatory and supervisory barriers to the development of FinTech in Poland and to prepare proposals for ways to eliminate them, as well as solutions and activities that could eliminate or reduce the identified barriers. osoby fizyczne, które nie zostały prawomocnie skazane za umyślne przestępstwo: przeciwko działalności instytucji państwowych oraz samorządu terytorialnego, przeciwko wymiarowi sprawiedliwości, wiarygodności dokumentów, mieniu, obrotowi gospodarczemu czy interesom majątkowym i obrotowi pieniędzmi, a także osoby prawne bądź jednostki organizacyjne, w których wspólnicy nie zostali prawomocnie skazani na zasadach określonych powyżej w stosunku do osób fizycznych lub za przestępstwo skarbowe.

Co również istotne, zgodnie z przedstawioną nowelizacją w zakresie instytucji obowiązanych prowadzących działalność w zakresie obrotu lub wymiany między kryptoaktywami a walutą fiducjarną, wprowadzono obowiązek raportowania do Generalnego Inspektora transakcji o równowartości 1000 euro oraz stosowania pełnego katalogu środków bezpieczeństwa finansowego, czy obowiązku weryfikacji klienta, w tym ustalenia danych osobowych, numeru PESEL lub daty urodzenia, numeru dokumentu tożsamości czy adresu, ustalenie danych beneficjenta rzeczywistego - czyli osoby faktycznie sprawującej kontrolę nad klientem. Przyczyną przeprowadzenia tej zmiany były analizy jednostki analityki finansowej realizowanych transakcji na tym rynku świadczonych przez kantory/giełdy kryptowalutowe oraz związane z tym ryzyka, jak również konieczność implementowania przepisów unijnych.

Kolejnym obszarem regulacji kryptoaktywów jest system podatkowy. Zgodnie z ustawą z dnia 26 lipca 1991 r. o podatku dochodowym od osób fizycznych [20] przychody z obrotu walutami wirtualnymi zakwalifikowano do przychodów z kapitałów pieniężnych lub zysków kapitałowych. Do powyższej kategorii zalicza się: sprzedaż, zapłatę kryptowalutą, regulowanie innych zobowiązań, sprzedaż na wolnym rynku, giełdzie lub w kantorze. Wskazano jednocześnie na szczególne zasady opodatkowania kryptoaktywami. Przychody te nie będą łączone z innymi przychodami z kapitałów pieniężnych (zysków kapitałowych). Kwalifikacja do źródła przychodów - kapitały pieniężne - dokonana zostanie nawet wtedy, gdy podatnik będzie osiągał przychody z obrotu walutami wirtualnymi w ramach prowadzonej działalności gospodarczej. W konsekwencji strata poniesiona $z$ obrotu walutami wirtualnymi nie będzie mogła być odliczona od innych dochodów podatnika, np. ze sprzedaży akcji, czy też z prowadzonej działalności gospodarczej.

W kontekście zysków osiąganych z obrotu kryptowalutą, w związku z prowadzoną działalnością gospodarczą, zastosowanie mają przepisy art. 7b ustawy z 15 lutego 1992 o podatku dochodowym od osób prawnych [21], w których przychody określono jako: sprzedaż, zapłatę kryptowaluta, regulowanie innych zobowiązań, sprzedaż na wolnym rynku, giełdzie, kantorze.

Podatek od osób fizycznych, jak i prawnych zawiera się w przedziale od 17 do $32 \%$, zgodnie ze skalą podatkową.

Oddzielnym zagadnieniem jest możliwość opodatkowania transakcji kryptowalutowych podatkiem VAT. Jednak zgodnie z interpretacją Ministerstwa Finansów „działalność w zakresie kupna i sprzedaży kryptowalut podlega opodatkowaniu VAT jako odpłatne świadczenie usług, dla celów VAT pojęcie walut używanych jako prawny środek płatniczy obejmuje również tzw. kryptowalutę. Oznacza to, że sprzedaż i wymiana kryptowaluty na walutę tradycyjną i odwrotnie, jak również wymiana jednej kryptowaluty na inną, o ile podlega opodatkowaniu VAT, korzysta ze zwolnienia z VAT" [22]. 
As part of the work of the Group in question, the Ministry of Finance proposed an optimal business model for exchanges/platforms dealing with cryptocurrency trading - the aforementioned small payment institution.

The most important requirements for this activity are:

- obtaining an entry in the register of a small payment institution kept by the Polish Financial Supervision Authority;

- the average total amount of payment transactions from the previous 12 months performed by a small payment institution (including the agents through which it provides payment services) may not exceed an amount equivalent to EUR 1,500,000 per month;

- having organizational solutions to calculate the total monthly amount of payment transactions;

- having solutions in the area of counteracting money laundering and financing terrorism;

- the total amount of measures adopted for one user at any time may not exceed the Polish currency equivalent of EUR 2,000.

In addition, a small payment institution may run a so-called hybrid activity. This means that an entity that is a small payment institution may also provide non-financial services. According to this solution, the conditions and criteria for running a business, in particular an entry in the register of services of a small payment institution, may be used by platforms/cryptocurrency exchange offices.

The Act does not exclude the possibility of conducting business activity by entities operating on the cryptoasset market as part of another form of payment services (i.e. a national payment institution, payment service offices), but these entities must already meet separate, more stringent regulatory requirements.

Also worth discussing are the assumptions of the draft regulation of the European Parliament and of the Council on cryptographic markets and amending Directive EU 2019/1937 of 24 September 2020 COM (2020) 593 [24], which includes a proposal to regulate cryptoassets, virtual currencies and tokens of utility and payment nature related to other assets. The regulatory concept in question is a breakthrough for the participants of this market, as well as for the development prospects of this market, because:

- it contains key market definitions, including the term cryptoassets, tokens as well as the issuer of cryptoassets;

- it describes the procedures related to the issuance of instruments such as cryptoassets, tokens, as well as the conditions and requirements for this emission;

- it indicates the measures necessary to implement activities which are to counteract specific irregularities.

The legal act in question does not have its final shape yet, but it will certainly be a breakthrough for the market of the cryptoassets, its development prospects, and most of all in the context of the security of transactions carried out on this market.
Kolejnym aspektem regulacji kryptoaktywów jest możliwość prowadzenia działalności gospodarczej dla giełd/kantorów w zakresie obrotu kryptowalutami na podstawie przepisów ustawy z dnia 19 sierpnia 2011 r. o usługach płatniczych [23]. Najdogodniejszą formą prowadzenia działalności w zakresie obrotu kryptowalutami w ramach tej ustawy, z uwagi na niskie wymogi regulacyjne, jest tzw. mała instytucja płatnicza.

1 grudnia 2016 r., z inicjatywy Komisji Nadzoru Finansowego, powołano Zespół roboczy ds. rozwoju innowacji finansowych (tzw. FinTech). Celem prac Zespołu była identyfikacja barier natury prawnej, regulacyjnej i nadzorczej dla rozwoju FinTech w Polsce oraz przygotowanie propozycji sposobów ich eliminacji, a także rozwiązań i działań, które mogłyby wyeliminować lub ograniczyć zidentyfikowane bariery.

W ramach prac przedmiotowego Zespołu Ministerstwo Finansów zaproponowało optymalny model działalności gospodarczej dla giełd/platform zajmujących się obrotem kryptowalutą - wspomnianą już małą instytucję płatniczą.

Najistotniejszymi wymogami dla tej działalności są:

- uzyskanie wpisu do rejestru małej instytucji płatniczej prowadzonego przez Komisję Nadzoru Finansowego;

- średnia całkowita kwota transakcji płatniczych z poprzednich 12 miesięcy wykonanych przez małą instytucję płatniczą (w tym przez agentów, za pośrednictwem których świadczy ona usługi płatnicze) nie może przekraczać kwoty stanowiącej równowartość 1500000 euro miesięcznie;

- posiadanie rozwiązań organizacyjnych pozwalających na wyliczenie całkowitej miesięcznej kwoty transakcji płatniczych;

- posiadanie rozwiązań w zakresie przeciwdziałania praniu pieniędzy oraz finansowaniu terroryzmu;

- łączna wysokość środków przyjętych dla jednego użytkownika w każdym czasie nie może przekroczyć równowartości 2000 euro w walucie polskiej.

Dodatkowo mała instytucja płatnicza może prowadzić tzw. działalność hybrydową. Oznacza to, że podmiot będący małą instytucją płatniczą może również świadczyć usługi niefinansowe. Zgodnie z tym rozwiązaniem warunki i kryteria prowadzenia działalności gospodarczej, a w szczególności wpis do rejestru usług małej instytucji płatniczej, może być wykorzystywany przez platformy/kantory obrotu kryptowalutą.

Ustawa nie wyklucza możliwości prowadzenia działalności gospodarczej przez podmioty działające na rynku kryptoaktywów w ramach innej z form usług płatniczych (czyli np. krajowej instytucji płatniczej, biura usług płatniczych), jednak podmioty te muszą spełniać już odrębne, bardziej rygorystyczne wymogi regulacyjne.

Warte omówienia są również założenia projektu rozporządzenia Parlamentu Europejskiego i Rady w sprawie rynków kryptograficznych oraz zmieniający dyrektywę UE 2019/1937 dnia 24 września 2020 r. COM (2020) 593 [24], w którym zawarto propozycję regulacji kryptoaktywów, wirtualnych walut oraz tokenów o charakterze użytkowym, płatniczym powiązane $z$ innymi aktywami. Przedmiotowa koncepcja regulacyjna ma przełomowy charakter dla uczestników tego rynku, jak również perspektyw rozwoju tego rynku, ponieważ: 
- zawiera kluczowe definicje dla rynku, w tym m. in. wyjaśnia znaczenie kryptoaktywów, tokenów, jak również emitenta kryptoaktywów;

- opisuje procedury związane z emisją instrumentów, takich jak: kryptoaktywa, tokeny czy warunki i wymogi dotyczące tej emisji;

- wskazuje na środki konieczne do realizacji działań w zakresie przeciwdziałaniu określonym nieprawidłowościom.

Przedmiotowy akt prawny nie posiada jeszcze ostatecznego kształtu, jednak na pewno będzie miał przełomowe znaczenie dla rynku kryptoaktywów, perspektyw jego rozwoju, ale przede wszystkim w kontekście bezpieczeństwa transakcji realizowanych na tym rynku.

\section{Contemporary threats to the economic security of the state and cryptoassets}

The term economic security is understood as "various activities (measures) in the area of national security, the main purpose of which is to ensure the economic conditions necessary for the survival, prosperity and sustainable development of the society, as well as the efficient operation of the state and its institutions, as well as the state obtained as a result of effective opposition to external and internal destructive factors that may lead to the developmental disorders" [25].

In case of economic security, we deal with its following dimensions:

1) "security of raw material (access to economically significant energy resources, water, metals, minerals - in the amount corresponding to the structure of the economy);

2) "food security (the ability of the state's economic system to ensure the physical and economic availability of food);

3) financial security:

- external (foreign debt and the ability to resist financial crises),

- internal (the ability of public finance systems to ensure financing of the national economy and the implementation of national interests" [26].

The most important threats in the context of economic security are:

- financial and energy crises;

- tax crime related to VAT fraud, evasion of tax obligations, excise crime related to illegal production, smuggling and marketing of tobacco and spirits without excise stamps;

- financial crime to the detriment of banks related to extortion of loans to the detriment of banks, leasing and factoring funds, as well as related to the operation of parabanks, on the Forex market;

- money laundering;

- crime to the detriment of the EU's financial interests related to the fraudulent use of EU financial support;

- unauthorized access to bank accounts by cyber criminals.

In the security environment of the market of cryptoassets, we can distinguish "threats of an internal nature - resulting from sets of various types of internal circumstances, specific

\section{Współczesne zagrożenia bezpieczeństwa ekonomicznego państwa a kryptoaktywa}

Termin bezpieczeństwo ekonomiczne jest rozumiany jako „różnorodne działania (środki) w dziedzinie bezpieczeństwa narodowego, których zasadniczym celem jest zapewnienie warunków gospodarczych koniecznych do przetrwania, dobrobytu oraz zrównoważonego rozwoju społeczeństwa, jak i sprawnego działania państwa i jego instytucji, a także stan uzyskany w wyniku skutecznego przeciwstawienia się zewnętrznym i wewnętrznym czynnikom destrukcyjnym mogącym doprowadzić do zaburzeń rozwojowych" [25].

W przypadku bezpieczeństwa ekonomicznego mamy do czynienia z następującymi jego wymiarami:

1) „bezpieczeństwo surowcowe (dostęp do istotnych gospodarczo surowców energetycznych, wody, metali, minerałów - w ilości odpowiadającej strukturze gospodarki);

2) bezpieczeństwo żywnościowe (zdolność systemu ekonomicznego państwa do zapewnienia fizycznej i ekonomicznej dostępności żywności);

3) bezpieczeństwo finansowe:

- zewnętrze (zadłużenie zagraniczne i zdolność przeciwstawienia się kryzysom finansowym),

- wewnętrzne (zdolność systemów finansów publicznych do zapewnienia finansowania gospodarki narodowej i realizacji interesów narodowych" [26]

Najistotniejszymi zagrożeniami w kontekście bezpieczeństwa ekonomicznego są:

- kryzysy finansowe i energetyczne;

- przestępczość podatkowa związana z wyłudzaniem podatku VAT, uchylanie się od obowiązków podatkowych, przestępczość akcyzowa związana z nielegalną produkcją, przemytem i wprowadzaniem do obrotu wyrobów tytoniowych i spirytusowych bez znaków akcyzy;

- przestępczość finansowa działająca na szkodę banków związana z wyłudzeniem kredytów na szkodę banków, funduszy leasingowych, factoringowych, jak również związana z działalnością parabanków, na rynku Forex;

- pranie pieniędzy;

- przestępczość na szkodę finansowych interesów UE związana z wyłudzeniami wsparcia finansowego UE;

- nieautoryzowany dostęp do rachunków bankowych przez cyberprzestępców. 
to a given entity, which cause or may cause a disturbance of its internal stability and harmonious development in various manifestations of its activity, including weakening of its position or even loss of the possibility of survival in the environment of its functioning, and external - resulting from sets of various types of circumstances appearing in the environment of a given entity, which cause or may cause similar or the same effects" [27].

Current knowledge on cryptoassets - primarily taking into account the size of the market, the number of instruments available on the market, regulation of the activity of this area and legislative perspectives, development in the area of use as a financial or payment instrument - shows that threats to state security related to the activities of individual investors in terms of cryptoassets are declining. In 2020, the value of stolen or fraudulent cryptocurrencies decreased by $57 \%$ to $\$ 1.9$ billion, according to a report by CipherTrace, a cryptocurrency security company. A year earlier, this amount reached USD 4.5 billion [28].

Cryptocurrencies are less and less of a threat in terms of money laundering - due to statutory regulations in the area of counteracting money laundering and terrorist financing, international cooperation of state services and cryptocurrency exchanges and exchange offices, as well as experience in blockchain analysis, as well as the development of analysis methods by business entities professionally dealing with the issues of cyberspace research. Confirmation of the existing threats related to the use of cryptocurrencies for money laundering or financing terrorism is the inclusion of the area of economic activity related to cryptocurrency trading in the National Assessment of Money Laundering and Financing Terrorism [29].

The available reports of Europol on the activities of organized crime groups (the so-called SOCTA report) [30] show that among the most common methods of money laundering - apart from cash smuggling, the use of economic activity, the activities of specialized groups - there are also new financial payment systems (methods), including cryptocurrencies, using the ability to hide the actual beneficiary of the transaction.

Europol distinguishes the three most common mechanisms of using the cryptocurrency market for money laundering:

- the use of business activity - a cryptocurrency exchange in the process of legalizing funds from organized crime;

- use of smurfing transactions involving the fragmentation of cash payments to bank accounts controlled by a criminal group, then mixing and transferring funds to exchanges or other cryptocurrency market institutions;

- transfer of funds to legalize them in foreign cryptocurrency exchanges.

Cryptoassets - due to the decreasing interest in traditional investment solutions (shares, investment funds) and the innovative nature of this instrument, as well as popularity in the economic media - can be used for various types of financial fraud. It is also worth pointing out that cryptoassets do not have an explicitly regulated legal status, so the emission, purchase, use, and trading in them may be associated with various types of risks, including in particular the inability to enforce claims related to the acquisition of a given cryptoasset, the risk of losing access to it, or a significant decrease in its value [31]. Moreover, due to the
W środowisku bezpieczeństwa rynku kryptoaktywów wyróżnić możemy „zagrożenia o charakterze wewnętrznym - wynikające ze zbiorów różnego rodzaju okoliczności wewnętrznych, właściwych danemu podmiotowi, które powodują lub mogą spowodować zakłócenie jego wewnętrznej stabilności i harmonijnego rozwoju w różnych przejawach jego aktywności, włącznie z osłabieniem pozycji lub nawet utratą możliwości przetrwania w środowisku jego funkcjonowania, oraz zewnętrze - wynikające ze zbiorów różnego rodzaju okoliczności pojawiających się w otoczeniu danego podmiotu, które powodują lub mogą spowodować podobne lub takie same skutki" [27].

Z aktualnej wiedzy dotyczącej kryptoaktywów - przede wszystkim z uwzględnieniem rozmiarów rynku, liczby instrumentów dostępnych na rynku, regulacji działalności tego obszaru oraz perspektyw legislacyjnych, rozwoju w zakresie wykorzystania jako instrument finansowy czy o charakterze płatniczym wynika, że zagrożenia dla bezpieczeństwa państwa związane z działalnością indywidualnych inwestorów w zakresie kryptoaktywów maleją. Według raportu firmy CipherTrace zajmującej się kwestiami bezpieczeństwa w obszarze kryptoaktywów, w $2020 \mathrm{r}$. wartość skradzionych lub wyłudzonych kryptowalut zmniejszyła się o $57 \%$ - do poziomu 1,9 mld USD. Rok wcześniej kwota ta sięgała 4,5 mld USD [28].

Kryptoaktywa w coraz mniejszym stopniu stanowią zagrożenia zarówno w zakresie prania pieniędzy - z uwagi na regulacje ustawowe w ramach przeciwdziałania praniu pieniędzy oraz finansowaniu terroryzmu, współpracę międzynarodową służb państwowych oraz z giełdami i kantorami kryptowalutami oraz doświadczenie w zakresie analizy blockchain, jak również wypracowanie metod analizy przez podmioty gospodarcze profesjonalnie zajmujące się problematyką badania cyberprzestrzeni. Potwierdzeniem istniejących zagrożeń związanych z wykorzystaniem kryptowalut do prania pieniędzy lub finansowania terroryzmu jest umieszczenie obszaru działalności gospodarczej związanego z obrotem kryptowalutą w Krajowej ocenie ryzyka prania pieniędzy oraz finansowania terroryzmu [29].

$Z$ dostępnych raportów Europolu na temat działalności zorganizowanych grup przestępczych (tzw. raport SOCTA) [30] wynika, że wśród najczęściej spotykanych metod prania pieniędzy - poza przemytem gotówki, wykorzystaniu działalności gospodarczej, działalności wyspecjalizowanych grup - występują również nowe systemy (metody) płatności finansowych (w tym kryptowalut), wykorzystujące możliwość ukrywania faktycznego beneficjenta transakcji.

Europol wyróżnia trzy najczęściej pojawiające się mechanizmy wykorzystania rynku kryptowalut do prania pieniędzy:

- wykorzystanie prowadzonej działalności gospodarczej - giełdy kryptowalutowej w procesie legalizowania środków finansowych pochodzących z przestępczości zorganizowanej;

- wykorzystanie transakcji smurfingowych polegających na rozdrabnianiu wpłat gotówkowych na kontrolowane przez grupę przestępczą rachunki bankowe, następnie mieszanie i transferowanie środków finansowych do giełd lub innych instytucji rynku kryptowalutowego;

- transfer środków finansowych w celu ich zalegalizowania w zagranicznych giełdach kryptowalutowych. 
technological development, cryptocurrencies are gaining more and more importance as an investment instrument. Therefore, they can operate in the areas of various regulations: the Act on Payment Services, the Act on Trading in Financial Instruments, and the Act on Investment Funds. As a result, they may pose a threat in various dimensions of the business activity, and the operations of which may imply:

- making fraud under the guise of making financial investments;

- conducting business activity in the area of trading in financial instruments without the permission of a competent authority - art. 178 of the Act on Trading in Financial Instruments;

- running a business against the provisions of the Payment Services Act (art. 150);

- due to the growing popularity of investment tokens, as well as the lack of regulation and supervision over this market segment, this area remains susceptible to irregularities.

It is worth noting that on 12 January 2021, the Polish Financial Supervision Authority once again issued a warning about the risks associated with the acquisition and trading of cryptoassets [32] (including virtual currencies and cryptocurrencies), which contains information about the following risks: regulatory risks, market instability, no guarantees of entrusted funds, the use of cryptocurrency mixers that anonymize the history of cryptocurrency transactions, as well as the risks of using cryptocurrency-based financial services that operate outside the financial supervision system.

It should be pointed that the level of security of entities operating in the cryptocurrency industry, carried out transactions, assets stored there, is constantly developing. However, irrespective of the above, the issue remains a challenge for the owners and managers of these entities. There is still no relevant legal provisions regulating the security of the IT systems of the companies operating in the cryptoassets industry (e.g. similar to the operation of the Bank Guarantee Fund), while the insurance of the stock exchange/currency exchange office itself, transactions and assets accumulated there, remain unprofitable for insurance companies, due to the risk of a situation covered by the contract.

Since there are no appropriate legal solutions, the liability issues related to the manipulations on the cryptoassets market are still relevant. "Market manipulation can be defined as a series of transactions involving the purchase or sale of securities with the aim of creating a false impression of an active market, or with the aim of raising or lowering market quotations in order to cause the securities to be sold or bought by other market participants" [33].

Characteristic methods of manipulating financial instruments for this market may be:

- "wash trade - carrying out a series of purchase or sale transactions of a financial instrument, but there is no change in the ownership of a specific investor/group of investors;

- painting the tape - carrying out a series of transactions about which information is available to the public in order
Kryptoaktywa - z uwagi na malejące zainteresowanie tradycyjnymi rozwiązaniami inwestycyjnymi (akcje, fundusze inwestycyjne) oraz innowacyjny charakter tego instrumentu, a także popularność w mediach ekonomicznych - mogą być wykorzystywane do różnego rodzaju oszustw finansowych. Warto również wskazać, iż kryptoaktywa nie posiadają uregulowanego wprost statusu prawnego, więc emisja, nabycie, korzystanie, a także obrót nimi może wiązać się z różnego rodzaju ryzykami, w tym w szczególności brakiem możliwości egzekucji roszczeń związanych z nabyciem danego kryptoaktywa, ryzykiem utraty do niego dostępu, czy też znacznego spadku jego wartości [31]. Ponadto kryptoaktywa z uwagi na rozwój technologiczny nabywają coraz większe znaczenie jako instrument o charakterze inwestycyjnym. W związku z powyższym mogą funkcjonować w obszarach różnych regulacji: ustawy o usługach płatniczych, ustawy o obrocie instrumentami finansowymi, ustawy o funduszach inwestycyjnych. Co za tym idzie, mogą stanowić zagrożenie w różnych wymiarach prowadzonej działalności gospodarczej. W tym zakresie za pomocą kryptoaktywów można:

- dokonywanie oszustw pod pozorem realizowania inwestycji finansowych;

- prowadzenie działalności gospodarczej w zakresie obrotu instrumentami finansowymi bez zezwolenia właściwego organu - art. 178 ustawy o obrocie instrumentami finansowymi;

- prowadzenie działalności gospodarczej wbrew przepisom ustawy o usługach płatniczych (art. 150);

- w związku ze wzrostem popularności tokenów o charakterze inwestycyjnym, jak również brakiem regulacji oraz nadzoru nad tym segmentem rynku, obszar ten pozostaje podatny na nieprawidłowości.

Warto odnotować, że 12 stycznia 2021 r. Komisja Nadzoru Finansowego po raz kolejny wydała ostrzeżenie o ryzykach związanych z nabywaniem oraz obrotem kryptoaktywami [32] (w tym walutami wirtualnymi oraz kryptowalutami), w którym zawarto informacje o zagrożeniach: ryzykach regulacyjnych, niestabilności rynku, braku gwarancji powierzanych środków finansowych, korzystaniu z mikserów kryptowalutowych, które anonimizują historię transakcji kryptowalutą, jak również ryzykach korzystania z usług finansowych opartych o kryptowalutę, które funkcjonują poza system nadzoru finansowego.

Należy zaznaczyć, że poziom bezpieczeństwa podmiotów działających w branży kryptowalut, realizowanych transakcji, przechowywanych tam aktywów, stale się rozwija. Jednak niezależnie od powyższego, przedmiotowa kwestia w dalszym ciągu pozostaje wyzwaniem dla właścicieli i osób zarządzających tymi podmiotami. W dalszym ciągu brakuje stosownych przepisów prawnych regulujących kwestie bezpieczeństwa systemów informatycznych firm działających w branży kryptoaktywów (np. zbliżonych do działalności Bankowego Funduszu Gwarancyjnego), natomiast kwestie ubezpieczenia samej giełdy/kantoru, realizowanych transakcji oraz zgromadzonych tam aktywów, pozostają dla firm ubezpieczeniowych nieopłacalne, z uwagi na ryzyko wystąpienia sytuacji objętej umową.

W związku z brakiem stosownych rozwiązań prawnych nadal aktualne są kwestie odpowiedzialności związanej z manipulacjami na rynku kryptoaktywów. „Manipulację rynkiem można 
to create the impression of increased interest in a specific financial instrument or increase in price;

- placing orders without the intention to execute them placing orders with a price limit higher/(lower) than the previously offered bid/ask prices and withdrawing them before execution;

- inflating the price of an instrument intended for sale (pump and dump) which means taking a long position in relation to the selected security, and then concluding further purchase transactions and disseminating (e.g. in forums) misleading positive information about this security in order to increase its prices" [34].

Cryptocurrencies, due to no appropriate regulations counteracting threats in the area of manipulation, are a susceptible market for the use of the practices mentioned above. Such phenomena are accompanied by the speculative nature of cryptoassets, the innovative nature of the instrument, the actual market instability, no market supervision, and no procedures specifying the requirements for informing market participants about exceeding the percentage of trade.

Another issue is the risks associated with the penetration of transaction mechanisms (cryptocurrencies) into traditional financial solutions. Cryptocurrencies are increasingly associated with services such as banking, investment and payment services. The Revolut company, providing financial services, offers its clients the opportunity to purchase cryptocurrencies via the cryptocurrency service, while Coinbase gives the possibility to borrow cryptocurrencies [35]. There are investment funds and ETFs (exchange traded funds - a fund listed on the stock exchange, reflecting the behaviour of a selected asset or index, characterized by low costs) or CFDs (contracts for difference), the portfolio of which provides the possibility of investing in cryptocurrency.

In connection with the above legal regulations, the acceptance of cryptoassets by other segments of the financial market, the constant increase in interest and the speculative nature of the market cryptoassets imply further threats related to the possibility of rapid changes in the prices of instruments related to the cryptoassets or even leads to the collapse of some projects. zdefiniować jako serię transakcji obejmujących kupno lub sprzedaż papierów wartościowych w celu stworzenia fałszywego wrażenia aktywnego rynku lub $w$ celu podniesienia lub obniżenia notowań rynkowych, by spowodować sprzedaż bądź kupno tych papierów przez innych uczestników rynku" [33].

Charakterystycznymi metodami manipulacji instrumentami finansowymi dla tego rynku mogą być:

- "sztuczny obrót (ang. wash trade) - przeprowadzanie szeregu transakcji kupna lub sprzedaży instrumentu finansowego, przy czym nie następuje zmiana posiadania określonego inwestora/grupy inwestorów;

- zafałszowywanie obrazu (ang. painting the tape) - przeprowadzanie szeregu transakcji, o których informacja dostępna jest publicznie, w celu wywarcia wrażenia zwiększonego zainteresowania określonym instrumentem finansowym lub wzrostu ceny;

- składanie zleceń bez zamiaru ich wykonywania - składanie zleceń z limitem cenowym wyższym/ (niższym) od wcześniej oferowanych cen kupna/sprzedaży i ich wycofywanie przed wykonaniem;

- zawyżanie ceny instrumentu przeznaczonego do sprzedaży (ang. pump and dump) polegające na zajęciu pozycji długiej w stosunku do wybranego papieru wartościowego, a następnie zawieraniu dalszych transakcji kupna oraz rozpowszechnianiu (np. na forach) wprowadzających $w$ błąd pozytywnych informacji na temat tego papieru wartościowego w celu podwyższenia jego cen" [34].

Kryptowaluty z uwagi na brak stosownych regulacji przeciwdziałających zagrożeniom w zakresie manipulacji, są podatnym rynkiem do stosowania wspomnianych praktyk. Takim zjawiskom towarzyszy spekulacyjny charakter kryptoaktywów, innowacyjny charakter instrumentu, faktyczna niestabilność rynku, brak nadzoru nad rynkiem, brak procedur określających wymogi informowania uczestników rynku o przekroczeniu procentowej wysokości obrotu.

Kolejną kwestią są ryzyka związane z przenikaniem mechanizmów transakcyjnych (kryptowalut) do tradycyjnych rozwiązań finansowych. W coraz większym stopniu kryptoaktywa powiązane są z takimi usługami jak: usługi bankowe, inwestycyjne czy płatnicze. Firma Revolut, świadcząca usługi finansowe, oferuje swoim klientom możliwość nabywania za pośrednictwem serwisu kryptowalut, firma Coinbase daje z kolei możliwość pożyczania kryptowalut [35]. Powstają fundusze inwestycyjne oraz ETF (ang. exchange traded fund - fundusz notowany na giełdzie, odwzorowujący zachowanie wybranego aktywa lub indeksu, cechujący się niskimi kosztami) czy CFD (ang. contract for difference - kontrakty na różnicę cenową), których portfel przewiduje możliwość inwestycji w kryptoaktywa.

W związku z powyższym regulacje prawne, akceptacja kryptoaktywów przez inne segmenty rynku finansowego, stały wzrost zainteresowania oraz spekulacyjny jednak charakter rynku kryptoaktywów implikuje kolejne zagrożenia związane z możliwością gwałtownych zmian cen instrumentów powiązanych z kryptoaktywami lub wręcz prowadzi do upadku niektórych projektów. 


\section{Summary}

Due to its technological, legal, economic and organizational structure, the market of cryptoassets in Poland poses a threat to the financial security of the state. However, due to the size of this market, its dispersed nature, and attempts to regulate, this threat is sector-specific and concerns such areas as: money laundering, financing terrorism, financial fraud, including the use of ICO (initial coin offering) and ITO (initial token offering), manipulation of values, concealing property from various forms of crime.

Cryptocurrencies are subject to national legal regulations that cover aspects of:

- civil law regarding the recognition of this asset in terms of property law;

- counteracting money laundering and financing terrorism;

- providing payment services;

- taxation of income from cryptoassets.

It should be added that the European Parliament is working on a comprehensive solution for the regulation of cryptoassets. The prepared legal act will be crucial for the recognition of these assets by the financial, payment and investment services market.

Polish financial supervision institutions, a financial intelligence unit, tax services, services dealing with the protection of the financial interests of the state as well as law enforcement identify threats related to the trading of cryptoassets. In 2018, the Prime Minister of the Republic of Poland appointed a Working Group for the analysis of significant threats to the security and the interests of consumers and the state in the economic and financial sphere in order for the competent authorities to analyze threats to the financial security of the state and to develop recommendations for the effective measures to mitigate these risks. This fact confirms that the problem of cryptoassets has been noticed and assessed as significant from the point of view of the financial interests of the state.

It is also worth presenting selected activities of the national authorities - the General Inspector of Financial Information issued on 14 July 2014 the Communication on the dangers of virtual currencies [36], also in the context of threats related to their use for money laundering, as well as signaling potential irregularities in the annual reports on its activities. Moreover, the issue of cryptoassets was indicated as a risk factor in the National Assessment of Money Laundering and Financing Terrorism [37].

On 22 November 2017, the Polish Financial Supervision Authority published a Communication on the sale of the so-called coins or tokens (Initial Token Offerings - ITOs or Initial Coin Offerings - ICOs) [38]. The public emission of cryptocurrencies is a new way of obtaining funds in a public way, using the so-called tokens or coins. By purchasing a token, the buyer obtains certain rights, most often related to the promise of issuing a unique cryptocurrency.

On 7 July 2017, the Communication of the National Bank of Poland and the Polish Financial Supervision Authority on virtual currencies was published [39]. The document in question indicates the legality of trading in this instrument, and at the same time specifies the risk related to virtual currencies:

- the risk related to the possibility of losing funds due to theft;

\section{Podsumowanie}

Rynek kryptoaktywów w Polsce - ze względu na konstrukcję technologiczną, prawną, ekonomiczną i organizacyjną - stanowi zagrożenie dla bezpieczeństwa finansowego państwa. Jednak z uwagi na rozmiary tego rynku, rozproszony charakter, podejmowane próby regulacji, zagrożenie to ma charakter sektorowy i dotyczy takich obszarów jak: pranie pieniędzy, finansowanie terroryzmu, oszustwa finansowe w tym przy wykorzystaniu procedur ICO (ang. initial coin offering) i ITO (ang. initial token offering), manipulacja wartością, ukrywanie mienia pochodzącego z różnych form przestępczości.

Kryptoaktywa podlegają krajowym regulacjom prawnym, które dotyczą aspektów:

- prawa cywilnego w zakresie uznawania tego aktywa w kategoriach prawa majątkowego;

- przeciwdziałania praniu pieniędzy oraz finansowaniu terroryzmu;

- prowadzenia usług o charakterze płatniczym;

- opodatkowania dochodów pochodzących z kryptoaktywów.

Dodać należy, iż Parlament Europejski pracuje nad kompleksowym rozwiązaniem w zakresie regulacji kryptoaktywów. Przygotowany akt prawny będzie miał przełomowe znaczenie dla uznawania tych aktywów przez rynek finansowy, usług płatniczych i inwestycyjnych.

Polskie instytucje nadzoru finansowego, jednostka analityki finansowej, służby skarbowe, służby zajmujące się ochroną finansowych interesów państwa jak również ścigania identyfikują zagrożenia związane z obrotem kryptoaktywami. Prezes Rady Ministrów RP w 2018 r. powołał Zespół roboczy ds. analizy istotnych zagrożeń bezpieczeństwa oraz interesów konsumentów i państwa w sferze gospodarczej i finansowej w celu dokonania przez właściwe organy analizy zagrożeń dla bezpieczeństwa finansowego państwa oraz wypracowania rekomendacji skutecznych działań ograniczających te ryzyka. Fakt ten potwierdza, że problem kryptoaktywów z punktu widzenia interesów finansowych państwa został dostrzeżony oraz oceniony jako istotny.

Warto również przedstawić wybrane aktywności organów krajowych - Generalny Inspektor Informacji Finansowej wydał 14 lipca 2014 r. Komunikat w sprawie niebezpieczeństw związanych $z$ walutami wirtualnymi [36], w tym również $w$ kontekście zagrożeń związanych z wykorzystaniem ich do prania pieniędzy, jak również sygnalizuje potencjalne nieprawidłowości w sprawozdaniach rocznych ze swojej działalności. Ponadto problematyka kryptoaktywów została wskazana jako czynnik ryzyka w Krajowej ocenie ryzyka prania pieniędzy oraz finansowaniu terroryzmu [37].

22 listopada 2017 r. Komisja Nadzoru Finansowego opublikowała Komunikat w sprawie sprzedaży tzw. monet lub tokenów (Initial Token Offerings - ITOs lub Initial Coin Offerings - ICOs) [38]. Emisja publiczna kryptowalut jest nowym sposobem pozyskiwania środków w sposób publiczny, z zastosowaniem tzw. tokenów lub monet. Przez zakup tokena nabywca uzyskuje określone uprawnienia, najczęściej związane z obietnicą emisji unikalnej kryptowaluty.

7 lipca 2017 r. opublikowano Komunikat Narodowego Banku Polskiego i Komisji Nadzoru Finansowego w sprawie "walut" wirtualnych [39]. W przedmiotowym dokumencie wskazano na 
- the risk related to the lack of a guarantee of assets;

- the risk related to the lack of universal acceptability;

- the risk related to the possibility of fraud in virtual currency trading;

- the risk related to the possibility of changing the price.

Notwithstanding the above, under the Program for Counteracting and Combating Economic Crime for 2015-2020 [40], the police also identified risks related to the possibility of using virtual currencies for money laundering and cybercrime. Moreover, the identification and prevention of threats should primarily take place through the following activities:

- creating a supervisory authority competent in cryptoassets matters or extending the competences of an existing office (e.g. the Polish Financial Supervision Authority) in order to take appropriate supervisory, operational and analytical activities;

- developing the best legal and institutional solutions in the area of international cooperation of services dealing with cyber threats;

- cooperation between institutions in the area of increasing theoretical and practical knowledge on cryptoassets, the legal dimension of regulation, the functioning of market mechanisms, and identified threats;

- cooperation between public institutions and the private sector in the area of: information exchange on cryptoassets - primarily with stock exchanges/cryptocurrency exchange offices, as well as centres specializing in blockchain analysis;

- international cooperation - in the area of EU supervisory institutions over the banking and capital market, or implemented by individual services (e.g. Europol);

- carrying out joint research and development projects

- appointing joint teams to identify threats and develop mitigating measures.

In connection with the above, it should be emphasized that national institutions and services dealing with the financial interests of the state perceive the problem of threats related to the use of cryptoassets for illegal activities and take appropriate information and operational measures to counteract these vulnerabilities. However, the constantly evolving market, instruments and options available within this market pose a challenge to state services, regulators and analysts dealing with the state's financial security and cyber threats. legalność obrotu tym instrumentem, jednocześnie określono ryzyko związane z wirtualnymi walutami:

- ryzyko związane z możliwością utraty środków z powodu kradzieży;

- ryzyko związane z brakiem gwarancji aktywów;

- ryzyko związane z brakiem powszechnej akceptowalności;

- ryzyko związane z możliwością oszustwa w obrocie wirtualnymi walutami;

- ryzyko związane z możliwością zmiany ceny.

Niezależnie od powyższego w ramach Programu przeciwdziałania i zwalczania przestępczości gospodarczej na lata 2015-2020 [40], policja również identyfikowała ryzyka związane z możliwością wykorzystania wirtualnych walut do prania pieniędzy oraz cyberprzestępczości. Ponadto identyfikacja i przeciwdziałanie zagrożeniom powinno odbywać się przede wszystkim przez następujące działania:

- stworzenie organu nadzoru właściwego w sprawach kryptoaktywów lub rozszerzenie kompetencji istniejącego już urzędu (np. Komisji Nadzoru Finansowego), celem podjęcia stosownych działań nadzorczych, operacyjnych i analitycznych;

- wypracowanie najlepszych rozwiązań prawnych i instytucjonalnych w sferze międzynarodowej współpracy służb zajmujących się cyberzagrożeniami;

- współpracę pomiędzy instytucjami w zakresie podnoszenia wiedzy teoretycznej i praktycznej dotyczącej kryptoaktywów, prawnego wymiaru regulacji, funkcjonowania mechanizmów rynkowych, identyfikowanych zagrożeń;

- współpracę pomiędzy instytucjami publicznymi a sektorem prywatnym w zakresie: wymiany informacji dotyczącej kryptoaktywów - przede wszystkim z giełdami/ kantorami kryptowalut, jak również ośrodkami specjalizującymi się w analizie łańcucha blockchain;

- współpracę międzynarodową - w zakresie unijnych instytucji nadzorczych nad rynkiem bankowym i kapitałowym, czy też realizowaną przez poszczególne służby (np. Europol);

- realizowanie wspólnych projektów naukowo-badawczych;

- powoływanie wspólnych zespołów identyfikujących zagrożenia oraz wypracowujących środki mitygujące.

W związku z powyższym należy podkreślić, że krajowe instytucje i służby zajmujące się finansowymi interesami państwa, dostrzegają problem zagrożeń związanych z wykorzystywaniem kryptoaktywów do nielegalnej działalności oraz podejmują stosowne działania o charakterze informacyjnym i operacyjnym w celu przeciwdziałania tym podatnościom. Jednak stale rozwijający się rynek, instrumenty i opcje dostępne w ramach tego rynku stanowią wyzwanie dla służb państwowych, organów regulacyjnych i analityków zajmujących się bezpieczeństwem finansowym państwa i cyberzagrożeniami. 


\section{Literature / Literatura}

[1] Aleksandrowicz T.R., Świat w sieci. Państwa. Społeczeństwa. Ludzie. W poszukiwaniu nowego paradygmatu bezpieczeństwa narodowego, Warszawa. 2018, 238.

[2] Internetowy słownik języka polskiego PWN [dostęp: 28.10.2021].

[3] Słownik terminów z zakresu bezpieczeństwa narodowego, AON, Warszawa 2008, 172.

[4] Aleksandrowicz T.R., Kluczowe megatrendy w bezpieczeństwie państwa XXI w., Warszawa 2020.

[5] https://www.pb.pl/inwestorzy-stawiaja-na-jachty-motorowe-1005716 [dostęp: 28.10.2021].

[6] https://www.ecb.europa.eu/pub/pdf/other/virtualcurrencyschemes201210en.pdf [dostęp: 28.10.2021].

[7] https://www.ecb.europa.eu/pub/pdf/other/virtualcurrencyschemesen.pdf [dostęp: 25.10.2021].

[8] https://www.esma.europa.eu/sites/default/files/library/ esma50-157-1391_crypto_advice.pdf [dostęp: 25.10.2021].

[9] https://www.eba.europa.eu/sites/default/documents/ files/documents/10180/2545547/67493daa-85a8-4429-aa91-e9a5ed880684/EBA\%20Report\%20on\%20crypto\%20 assets.pdf [dostęp: 25.10.2021].

[10] Financial Conduct Authority, Guidance on Cryptoassets, Consultation Paper CP19/3, January 2019, 9.

[11] Opitek P., Pranie pieniędzyi finasowanie terroryzmu z wykorzystaniem walut wirtualnych, Instytut Kościuszki, Brief Programowy, https://ik.org.pl/wp-content/uploads/ik_brief_programowy_ pranie-pieniedzy-i-finasowanie-terroryzmu-z-wykorzystaniem-walut-wirtualnych.pdf [dostęp: 25.10.2021].

[12] Bela S., Kopyściański T., W. Srokosz W., Kryptowaluty jako elektroniczne instrumenty płatnicze bez emitenta. Aspekty informatyczne, ekonomiczne i prawne, Wrocław 2016, 52.

[13] Zacharzewski K., Bitcon jako przedmiot stosunków prawa prywatnego, Monitor Prawniczy 21/2004, 1133, https:// repozytorium.umk.pl/bitstream/handle/item/2866/46. pdf?sequence $=1$ [dostęp: 03.12.2021].

[14] Ustawa z dnia 1 marca 2018 r. o przeciwdziałaniu praniu pieniędzy i zapobieganiu terroryzmowi (Dz. U. 2021, poz.1132, z późn. zm.).

[15] Hara M., Kierzynka R., Kołodziejski P., Ustawa o przeciwdziałaniu praniu pieniędzy oraz finansowaniu terroryzmu. Komentarz, Wyd. Lexis Nexis, Warszawa, 2014, 25.

[16] https://www.eba.europa.eu/ [dostęp: 28.10.2021].

[17] Ustawa z dnia 29 lipca 2005 r. o obrocie instrumentami finansowymi (Dz. U. 2005 r., nr 183, poz. 1538).

[18] Ustawa z dnia 1 marca 2021 r. o zmianie ustawy o przeciwdziałaniu praniu pieniędzy oraz finansowaniu terroryzmu oraz niektórych innych ustaw (Dz. U. 2021, poz.1132, z późn. zm.).

[19] Ustawa z dnia 30 marca 2021 r. o zmianie ustawy o przeciwdziałaniu praniu pieniędzy oraz finansowaniu terroryzmu oraz niektórych innych ustaw (Dz. U. 2021, poz. 815).

[20] Ustawa z dnia 26 lipca 1991 r. o podatku dochodowym od osób fizycznych (Dz. U. 2021., poz. 1128 z późń. zm.).

[21] Ustawa z 15 lutego 1992 o podatku dochodowym od osób prawnych (Dz. U. 2020, poz. 1406 z późń. zm.).
[22] Skutki podatkowe obrotu kryptowalutami w PIT, VAT i PCC, Komunikat Ministerstwa Finansów z 4 kwietnia 2018 r., https://www.kis.gov.pl/wiadomosci/aktualnosci/-/asset_ publisher/JSs9/content/id/7793320 [dostęp: 28.10.2021].

[23] Ustawa z dnia 19 sierpnia 2011 r. o usługach płatniczych (Dz.U. 2011., Nr 199, poz. 1175).

[24] Projekt rozporządzenia Parlamentu Europejskiego i Rady z dnia 24 września 2020 r. w sprawie rynków kryptograficznych oraz zmieniający dyrektywę UE 2019/1937, https://eur-lex.europa.eu/legal-content/EN/TXT/?uri=CELEX\%3A52020PC0593 [dostęp: 28.10.2021].

[25] Gryz J., Kitler W. (red.), Identyfikacja, klasyfikacja, podział i uzasadnienie pojęcia, istoty składników i zakresu bezpieczeństwa państwa, Wyd. AON, Warszawa 2014, 33.

[26] Księżopolski K.M., Bezpieczeństwo ekonomiczne, Dom Wydawniczy Elipsa, Warszawa 2011, 22.

[27] Kitler W., Bezpieczeństwo narodowe RP. Podstawowe kategorie. Uwarunkowania. System, Wyd. AON, Warszawa 2011, 60.

[28] Stasiuk T., W 2020 r. było mniej przestępstw związanych z kryptowalutami, „Puls Biznesu” 2021, https://www. pb.pl/w-2020-r-bylo-mniej-przestepstw-zwiazanych-z-kryptowalutami-1106786 [dostęp: 04.09.2021].

[29] Ministerstwo Finansów, Krajowa ocena ryzyka prania pieniędzy oraz finansowania terroryzmu, Warszawa 2019, https:// www.gov.pl/web/finanse/krajowa-ocena-ryzyka-prania-pieniedzy-oraz-finansowania-terroryzmu [dostęp: 04.09.2021].

[30] https://www.europol.europa.eu/socta-report [dostęp: 04.09.2021].

[31] Stanowisko Urzędu Komisji Nadzoru Finansowego w sprawie wydawania i obrotu kryptoaktywami, https://www.knf. gov.pl/knf/pl/komponenty/img/Stanowisko_UKNF_ws_ wydawania_i_obrotu_kryptoaktywami_71794.pdf, [dostęp: 07.09.2021].

[32] Ostrzeżenie Urzędu Komisji Nadzoru Finansowego o ryzykach związanych z nabywaniem oraz z obrotem kryptoaktywami w tym walutami wirtualnymi oraz kryptowalutami), https://www.knf.gov.pl/knf/pl/komponenty/img/ Ostrzezenie_UKNF_o_ryzykach_zwiazanych_z_nabywaniem_oraz_z_obrotem_kryptoaktywami_72241.pdf [dostęp: 07.09.2021].

[33] Iczetkin A., Hernik A., Manipulacje i oszustwa na rynku kapitałowym, "Finanse i Prawo Finansowe” 2019, 3(23), 9-24, http://www. finanseiprawofinansowe.uni.lodz.pl/Publikacje/24/1_Iczetkin_Hernik.pdf [dostęp: 28.10.2021].

[34] Huczek S., Manipulacja instrumentami finansowymi, $2013 r$., https://www.ncbiuletyn.pl/czytaj/1552-m anipulacja-instrumentami-finansowymi-cz-1-2.html [dostęp: 28.10.2021].

[35] SEC grozi pozwaniem Coinbase w związku z pożyczkami kryptowalutowymi, https://www.pb.pl/sec-grozi-pozwaniem-coinbase-w-zwiazku-z-pozyczkami-kryptowalutowymi-1126819 [dostęp: 10.09.2021].

[36] https://mf-arch2.mf.gov.pl/web/bip/ministerstwo-finansow/dzialalnosc/giif/komunikaty/-/asset_ publisher/8KnM/content/id/2955254 [dostęp: 10.09.2021]. 
[37] https://www.gov.pl/web/finanse/krajowa-ocena-ryzyka-prania-pieniedzy-oraz-finansowania-terroryzmu [dostęp: 28.10.2021]

[38] https://www.knf.gov.pl/o_nas/komunikaty?articleId=60178\&p_id=18 [dostęp: 28.10 .2021 ]
[39] https://www.knf.gov.pl/o_nas/komunikaty?articleId=57363\&p_id=18 [dostęp: 28.10 .2021$]$.

[40] http://isap.sejm.gov.pl/isap.nsf/download.xsp/ WMP20150001069/O/M20151069.pdf [dostęp: 28.10.2021].
JACEK CHARATYNOWICZ, PH.D. - has a PH.D. degree in security sciences, in his research work he takes up the subject of economic aspects of security in the context of threats related to new technologies (cryptoassets).
DR JACEK CHARATYNOWICZ - doktor nauk o bezpieczeństwie, w swojej pracy badawczej podejmuje tematykę ekonomicznych aspektów bezpieczeństwa w kontekście zagrożeń związanych z nowymi technologiami (kryptoaktywa). 